\title{
Kiswahili Verbs: A Lexicographical Challenge
}

\author{
Z.s.m. Mochiwa, Department of Kiswahili, The Open University of Tanzania, \\ Dar Es Salaam, Tanzania (zasamociwa@yahoo.com)
}

\begin{abstract}
This article makes three significant claims about Kiswahili verbs. By investigating the verbal root pend- 'love' the article claims that the agglutinative nature of Bantu languages is at the core of the morphological fecundity of Kiswahili verbs. Evidenced both vertically and horizontally, the fecundity brings in, respectively, extensions and derivations. The article claims further that each of the extensions of the verb can, theoretically at least, participate in derivational processes. The second claim is that this fecundity triggers lexicographical problems of choice and semantic analysis. Specifically, the article underscores the need for selectivity of information to control the density of the dictionary entry. Yet, selectivity presupposes a thorough analysis of the morphosyntactic behaviour of the verb in its many extended and derived forms. Indeed, such an analysis presupposes, in turn, an eclectic use of many linguistic theories. Bantu lexicography must be up front in making theoretically sound decisions. Finally, on the basis of linguistic theories, lexicography becomes a concretization of the mental lexicon claimed to be part of the competence of the native speaker.
\end{abstract}

Keywords: KISWAHILI, VERBS, LEXICOGRAPHY, LEXICON, DICTIONARY, INFLECTION, EXTENSION, DERIVATION, CAUSATIVE, SOUND-MEANING, ROOT, CITATION

Opsomming: Kiswahiliwerkwoorde: 'n Leksikografiese uitdaging. Hierdie artikel maak drie betekenisvolle bewerings oor Kiswahiliwerkwoorde. Deur 'n ondersoek van die verbale kern pend- "liefhê" beweer die artikel dat die agglutinerende aard van die Bantoetale aan die kern lê van die morfologiese vrugbaarheid van Kiswahiliwerkwoorde. Soos sowel vertikaal as horisontaal getoon, lei die vrugbaarheid tot suffiksering en afleiding onderskeidelik. Die artikel beweer verder dat elk van die agtervoegsels van die werkwood, teoreties altans, aan die afleidingsprosesse kan deelneem. Die tweede bewering is dat hierdie vrugbaarheid leksikografiese probleme van keuse en semantiese ontleding veroorsaak. Die artikel onderstreep veral die noodsaaklikheid van die selektiwiteit van inligting om die digtheid van die woordeboekinskrywing te beheer. Selektiwiteit veronderstel egter ' $n$ deeglike ontleding van die morfosintaktiese gedrag van die werkwoord in sy talle gesuffikseerde en afgeleide vorme. Op sy beurt veronderstel so 'n ontleding inderdaad 'n eklektiese gebruik van talle taalkundige teorieë. Bantoeleksikografie moet die eerste wees in die maak van teoreties gegronde besluite. Op grond van linguistiese teorieë word die leksikografie uiteindelik 'n konkretisering van die mentale leksikon wat na bewering deel van die vermoë van die moedertaalspreker is.

Sleutelwoorde: KISWAHILIWERKWOORDE, LEKSIKOGRAFIE, LEKSIKON, WOORDEBOEK, VERBUIGING, SUFFIKSERING, OORSAAKLIK, KLANK-BETEKENIS, KERN, AANHALING 


\section{Introduction}

A dictionary is the result of an all-encompassing sociolinguistic research. According to Gleason (1967: 101), a dictionary is 'the meeting place of all the systems, linguistic and non-linguistic which bear relevantly on speech behavior'. The linguistic side of the project reveals all, or, at least, as many as possible of, the idiosyncrasies of the language system of which the dictionary is compiled. In the light of this, a dictionary must enable the user to come face to face with the arbitrary nature of the language. Put somewhat succinctly, a dictionary reveals the non-correspondence between form and meaning in language.

Looked at from this same angle, a dictionary may be considered as being a near mirror image of the lexicon claimed to be part of a native speaker's competence. According to generative grammarians, this lexicon in the native speaker's mind contains a list of morphemes whose meanings cannot be predicted by mere inspection of their forms. One is tempted to add here that the dictionary is in many respects a concretization of the mental lexicon native speakers are claimed to have. Representing this school of thought, Kenstowicz and Kisseberth (1979: 3) state:

In generative grammar it is assumed that the morphemes of a language are stored by the speaker in a special listlike device called a lexicon or dictionary, which contains all of the truly unpredictable, idiosyncratic information about the behavior - syntactic, semantic, phonological — of each morpheme known to the speaker.

Although a parallel can be drawn between the dictionary and the lexicon, the latter is much more detailed than the former. This means that the compilation of the dictionary goes hand in hand with some deliberate selectivity. Bearing in mind the anticipated user's needs of the dictionary being compiled, lexicographers are forced to select certain types of information. What is more, considerations outside the field have considerable influence on lexicographers' work. These include usability of the product, cost issues and possibly the size of the finished product. These important considerations made Zgusta (1971: 16, 17) sound the following warning to lexicographers:

The lexicographer is doing scientific work, but ... he publishes it for users whose pursuits are always more practical, at least as regarded from his own point of view ... In other words, the user of the dictionary does not wish, at least usually, to have the purely lexicographic problems presented, but to have them solved.

As has already been pointed out, the density of information included in a dictionary varies, depending on the anticipated user. A learner's dictionary will be different from one for the use of a native speaker. The lexicographer rightly assumes that the user, being a native speaker of the target language, has acquired an exhaustive grammatical competence. The user's grammatical competence, for example, obviates the need for recording some of the morphological processes characteristic of the language. To the learner, however, the dic- 
tionary is a tool for learning the target language. It must contain information that will enable him/her to acquire competence in it.

In their bid to control the density of information to be recorded in their dictionaries, Bantu lexicographers are, time and time again, uncertain of what to include. As a result they tend to lay undue emphasis on matters of frequency regardless of the target user. In accordance with the extent to which users try to acquire the target language exhaustively, lexicographers must ensure that the morphology of the most frequently used words are given. The overall success of lexicographers' products depends to a large extent on what they choose to record.

One is, however, apt to point out that the choice of what to include must be such that the given information enables the user to acquire an accurate account of the morphological structure of the language. This is further emphasized by Prinsloo and De Schryver (2001: 188) who claim, among others:

The basic aim of the lexicographer is to guide the user in respect of the properties/features/characteristics/use/meaning of the lemma, i.e., to know the word.

To be more precise, a dictionary representing the native speaker's lexicon must accurately characterize both the inflections and derivations found in the language being described.

\section{The problem}

The agglutinating characteristic of Bantu languages affects verbs more significantly than they do other categories. Verbs change morphologically as they receive affixes either horizontally or vertically. They receive affixes horizontally during extensions or, more precisely, during their inflections. Kiswahili, for example, has, according to Kiango (2000: 104), eight verbal affixes ${ }^{1}$. Among these, three are less productive while the other five are very much so.

The five productive affixes present formidable problems to the lexicographer in two ways. On the one hand, a single root of a verb can use a given affix twice or even more. On the other hand, each root that has acquired a suffix can, at least theoretically, participate in the vertical morphological process of derivation ${ }^{2}$. This means, any root that acquires an affix can nominalize or deverbalize into an adjective.

The theoretical implication of this behaviour is that any verb in these languages is a 'word factory', so to speak. Many scholars, including Vitale (1981), Bokamba (1981), Keach (1985), and Prinsloo and De Schryver (2001), among many others, account for this state of affairs by appealing to the morphology with which Kiswahili is endowed. All of them claim that its complex morphology is entwined with its syntax. According to Givón (1971), the complexity is a result of the loss of syntactic features which forced otherwise free morphemes to be bound.

We are apt to ask: How can a Kiswahili verb then be exhaustively treated 
in a dictionary? Put somewhat differently: Can the lexicographer record and analyze each and every form that derives from the simple root? Is it possible to use a single verb entry for all its extensions as well as its derivatives such as nouns and adjectives? In other words: Can the fecundity of a Kiswahili verbal root such as pend- 'love' fit into a single dictionary entry? If the answer to this question is "no", how does the lexicographer identify his/her lemmata? De Schryver and Prinsloo (2002) remind lexicographers that, if the modern Bantu dictionary is to be really practical and useful, all verbs and their derivations likely to be looked up need to be included.

The purpose of this article is to explore the morphological and semantic fecundity of pend- 'love', a simple verb root in Kiswahili. By looking at its horizontal as well as its vertical changes in the acquisition of affixes, our main focus will be on two important issues. On the one hand, we intend to show the morphological complexity of the forms, both verbal and deverbal, resulting from the affixation process of the root. On the other hand, we want to study the semantics of the resulting verbal forms.

The study is carried out in two ways. First, we study the morphosyntactic patterning of the suffixes. Issues such as which suffix precedes another and whether or not a single suffix can be used more than once will be within the interests of the article. Second, we study the type of meanings the resulting verbal forms express. Specifically, we want to establish whether or not the verbal forms express compositional meanings. Before we embark on this issue, we need to articulate a few, but fundamental, assumptions.

\section{Theoretical underpinnings}

A dictionary has been described as a repository of idiosyncracies (Kenstowicz and Kisseberth 1979). These idiosyncracies explain the arbitrary nature of language in general. The most widely acknowledged of these idiosyncrasies is the form-meaning relation. Meanings of words are, by and large, unpredictable. We cannot guess the meaning of a given word by inspecting its linguistic form. Thus, a dictionary is intended to reveal to the user, both the semantic and morphosyntactic peculiarities of words found in the language for which it is compiled.

Languages endowed with a complex morphology, as Bantu languages are, trigger many questions. The most problematic of these in Kiswahili lexicographical projects is the identification of citation forms to be entered in the dictionary. How many extensions deserve entries? How many of the derived forms must be treated as separate entries? If a single citation form is identified for a verbal root like pend- 'love' and the rest is left to the user, can he/she, being a learner, find his/her way through the linguistic maze?

Kiango (2000: 21) who notes this problem, argues that it is compounded by Western theories of lexicography. His argument is that lexicographers working on Bantu languages need to be careful with the use of theories which arose 
from typologically different languages. He observes the following:

Lexicographical theories and methods are applied to natural languages which by their nature, have different phonological, morphological and syntactical structures.

Although dictionaries differ depending on specific factors, most of which lie outside the lexicographical field, lexicographers exclude information said to be derivable from the grammatical competence of the user. In Kiswahili, for example, once cheka 'laugh' is semantically analyzed, one can 'safely' assume that the user can derive chekeka 'be laughable'.

It is, in this vein, that Kamusi ya Kiswahili Sanifu, 'The Standard Kiswahili Dictionary', henceforth KKS, cites a few verbal extensions after the treatment of each verb. However, this is fine as long as the dictionary is for the use of native speakers. Suppose now that the dictionary is for language learners ${ }^{3}$. They use a dictionary to learn both the morphosyntactic and semantic features of the target language.

Compiling a Kiswahili dictionary is a morphosyntactic project. The lexicographer must simultaneously and aptly deal with the morphology of the language, which, needless to say, is not only intricate but also triggers syntactic issues. When it is extended, a verb, for example, acquires new syntactic features, which affect the meaning it expresses. It is, as this article wants to argue, misleading to assume that the user will arrive at the forms omitted.

Although the majority of the languages are yet to be fully analyzed, lexicographers do not take much trouble in their study of the forms they enter into the dictionaries. More often than not, the user who is at the 'mercy' of the dictionary, is given words falsely claimed to be variants of each other. Yet, a close look at them reveals that each one is derived from a different verbal root. KKS, for example, claims that mpotovu and mpotevu are variants of each other.

The morphological histories of the two nouns reveal clearly that they are derivatives of two different verbs. The noun mpotovu is derived from the verb potoa 'corrupt' whereas mpotevu is derived from potea 'be lost'. Obviously, the two derived forms cannot express the same meaning. Mpotovu is 'someone who corrupts people' whereas mpotevu is 'a prodigal person/someone who tends to disappear'. Mpotevu also possesses the meaning of 'squanderer'.

That the two derivative nouns are treated as variants is indicative of the dearth of morphological analysis of the language. Indeed, this is like assuming on the lexicographers' part that the morphology of the target language can, and indeed does, produce synonyms. This is again, as this article wants to argue, a misconception. Lexicographers who have not had both rigorous and vigorous training in theoretical linguistics lack the apparatus needed to reveal the mysteries of words.

What this discussion aims to show is that lexicographers must, first and foremost, be theoretical linguists. Such lexicographers have the skills needed for undertaking the project. Given their training, they can resolve issues of a theoretical nature. According to Zgusta (1971: 19), 'some of the problems of 
lexicographic analysis and presentation are surprisingly general, irrespective of the language in question'.

Zgusta's observation is crucial despite Kiango's concern about the use of 'imported' theories. Zgusta underscores the theoretical fact that, at a certain level of abstraction, human languages are similar, if not identical altogether. Theories that conceptualize language at that level are the ones the lexicographer needs. Kiango's observation is equally valid, because the lexicographer needs language-specific parameters (cf. Radford 1997). In other words, both Zgusta's and Kiango's points of view are important for the lexicographer to take seriously.

The theoretical linguist is in a better position to conceptualize the nature of language. $\mathrm{He} / \mathrm{she}$ is in an informed position to deal with theoretical issues. A proper theoretical training makes the lexicographer adept at discovering the rule-governed nature of language.

The theoretical training emphasized here is a fundamental knowledge of the nature of language that guides the lexicographer in making the right decisions. The lexicographer is not supposed to display his/her linguistic expertise in the dictionary he/she is compiling. His/her linguistic expertise enables $\mathrm{him} /$ her to accurately characterize the idiosyncracies of the language.

Firmly grounded in theoretical linguistics, lexicographers would not confuse mpotovu and mpotevu. An extension such as chemkika purported to trigger from chemka 'boil' is another indication of theoretical misconceptions. With a good theoretical grounding, these misconceptions could be minimized to avoid the mistakes cited above which have, undoubtedly, far-reaching consequences for the learner.

A lexicographical theory is much broader than any ordinary linguistic theory. It covers, according to Zgusta (1971: 15), 'the whole structure of the language in question' and 'the culture of the respective community in all its aspects'. In the first issue of Leksikografičeskij sbornik bratislavský, he states:

The theory of lexicography is connected with all the disciplines which study the lexical system: semantics, lexicology, grammar, stylistics.

Knowing the importance of language theories, Weinreich (1967: 26) had occasion to lament 'the indifference lexicography displays towards its own methodology'. Clear theoretical and methodological apparatus is a good roadmap to lexicographical success. With this in mind, we can begin to investigate the verbal root pend-as it acquires suffixes. We will allow the root to acquire one suffix at a time.

\section{Extension suffixes}

The number of extension suffixes identified by Kiango (2000) differs from that of Khamis (1972) who claims that Kiswahili has eleven. According to Khamis, the suffixes are the mood, i.e. the vowel suffix (vs), the conversive/reversive 
suffix (crs), the intensive suffix (is), the static suffix (sts), the durative suffix (ds), the potential suffix (pos) ${ }^{4}$, the stative suffix (ss), the applicative (sometimes referred to as the prepositional/applied) suffix (as), the causative suffix (cs), the passive suffix (pas) and the associative/reciprocal suffix (rs).

Except for the conversive/reversive and the intensive, all the suffixes change both the morphosyntactic and semantic patterning of the resulting verbal forms. The conversive/reversive and the intensive suffixes change the semantics of the verbal forms but the morphosyntactic features remain the same.

When acquired by the root, the conversive/reversive suffix, for example, realized as $-u$ - or -0 -, makes it express an antonymic meaning. It changes the meaning from 'do' to 'undo'. Thus, for example, funga 'close', panga 'arrange' and choma 'pierce' respectively become fungua 'untie/open', pangua 'disarrange' and chomoa 'unpierce'.

The intensive suffix, on the other hand, adds vigour and/or continuity as semantic features to the action of the verb. Without it, the verbal roots pig-, chek- and end- respectively mean 'hit', 'laugh' and 'go'. On acquisition of the intensive suffix, however, the new verbal forms pigilia, chekelea and endelea respectively mean 'hit hard continuously', 'laugh continuously/repeatedly', 'go unabated/continue without stopping'. Apart from these semantic features added to them, the verbal forms acquire no syntactic features. Intransitive verbs, for example, remain intransitive and transitive verbs remain transitive.

For purposes of this article, we investigate five suffixes, namely, the applicative, the causative, the stative, the intensive and the associative/reciprocal. What we intend to establish is their morphosyntactic patterning as well as their semantic input. At the same time, we intend to find out whether or not, on acquisition of the suffixes, the resulting verbal forms express compositional meanings. This will specifically be our major focus when the verbal forms result from the acquisition of more than one suffix. To begin with, we follow the root pend- as it acquires one suffix at a time.

\subsection{One extension suffix}

The verbal root pend- attracts all the suffixes, except the conversive/reversive, the durative, and the static. That pend- cannot acquire these suffixes is exemplified by the unacceptability of the following verbal forms, each of which uses the root.

(1) penda 'love'

'pendaa 'love all over' (durative)

penda 'love' *pendama 'stay in love'(?) (static)

Other verbal roots, however, can acquire these suffixes as can be seen from the following:

(2) funga 'close'

fungua 'open/tie - untie' (conversive)

paka 'smear' pakaa 'smear all over' (durative)

tua 'perch' tuama 'perch and stay' (static) 
When the root pend-is allowed to acquire a suffix, the following verbal forms result:

(3)

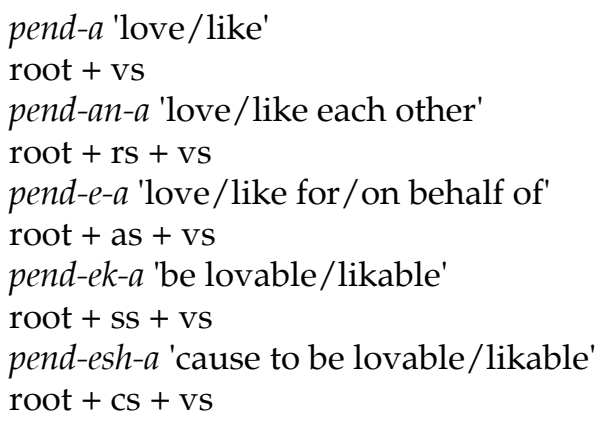

All the verbal forms under (3) above result after the root has acquired a certain suffix in addition to the vowel suffix. The first verbal form, however, is somewhat different from the others, because the root has acquired the vowel suffix only. The last verbal form does not seem to result from a direct acquisition of the causative suffix. It seems much more plausible and theoretically tenable to argue for the acquisition of the stative suffix prior to the causative suffix. Two reasons are adduced in support of this claim. On the one hand, the meaning expressed by the verbal form pendesha fits into the semantic frame 'cause to be verbable' rather than 'cause to verb'.

Thus, pendesha shares the same semantic frame with verbs derived from adjectives such as the following:

(4) fupi 'short'

kamili 'complete'

bora 'better'

refu 'long'

Such adjectives become verbs after the acquisition of the stative suffix thus:

(5) fupi-k-a 'become short/shorten'

kamili-k-a 'become complete'

bor-ek-a 'become refurbished/better than before'

Like pendeka 'become lovable', the stative verbal forms under (5) can acquire the causative suffix -sh- as under (6).

(6) fupisha 'cause to become short'

kamilisha 'cause to become complete'

boresha 'cause to become better than'

The causative suffix -sh- expresses the meaning in which someone or something triggers causation of and/or capability in which someone or something becomes verbed. The causative sh is specifically found with verbal forms that have acquired the stative suffix. Verbal forms that use sh for the causative fit into the semantic frame 'be verbable/become verbable'. 
The claim that the introduction of the causative suffix -sh-is indirect is supportable on phonological grounds. Verbal forms which take it are those which, when analyzed, have their roots ending in the velar stop / $\mathrm{k} /$ and, occasionally, the alveolar stop / $\mathrm{t}$. Such verbal forms almost invariably take the -sh-. Here are a few examples in addition to the above:

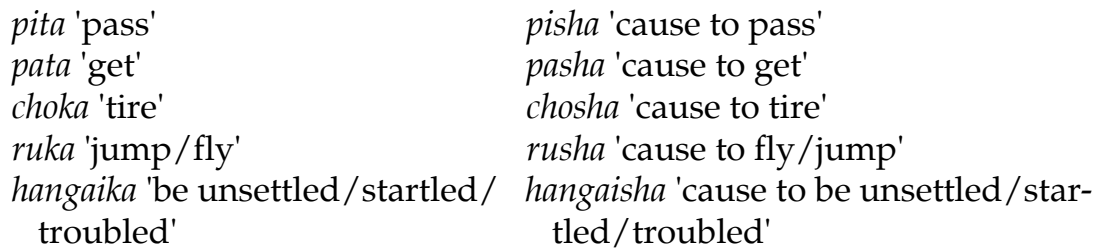

Although the article will not go into the details of the morphophonology involved, what can easily be seen happening is that the velar stop is replaced by the causative. Thus, the conclusion that can be drawn here is that verbal roots ending in $/ \mathrm{k} /$ or $/ \mathrm{t} /$ have their causative suffix in the form of a voiceless palatal fricative - sh-.

Some of the verbal forms with roots ending in the velar or alveolar stop are found to have two causative verbal forms or one but which is acquired after the stative. Without the stative suffix, the causative suffix derives the following verbal forms:

(8) (a) pita 'pass' pisha 'cause to be passable' pika 'cook' *pisha 'cause to be cooking/cooked' cheka 'laugh' *chesha 'cause to be laughable'

As can be seen, pisha as the causative of both pika and pita is not current in the language. This is partly due to the morphological clash in which the causative is forced to serve both verbs. If, however, the three verbs acquire their causative after their stative, the verbal forms which result are, without exception, current as becomes evident from the following set of data:

(8) (b) pita pikita itisha 'cause to be passable' pika pikika pikisha 'cause to be cooking/cooked' cheka chekeka chekesha 'cause to be laughable'

Thus, both pisha and pitisha are current in the language. The former means 'cause to pass', whereas the latter means 'cause to be passable'. Contrariwise, chesha does not seem to be current, although chekesha is indeed current. The stem -cheshi, however, is current because it is found in the noun mcheshi which means 'a jovial person'.

When the verbal root acquires the suffix, the resulting verbal form has the semantic frame 'cause to verb'. If, however, the causative is introduced after the stative suffix, the resulting verbal form means 'to cause to be verbed or verbable'. Thus, whereas pisha means 'cause to pass', pitisha means 'to cause to be passable'! The fact that pisha 'cause to cook' does not exist, is probably due to 
a possible clash between pisha from pita 'pass' and the causative of pika (pisha). Thus, pik-ik- 'be cookable' instead of pik 'cook' is allowed to causativize.

An immediate counterexample to the above claim is the verbal root $f$ - 'die'. This root extends to fisha 'cause to die'. It cannot be argued that $f a$ 'die' extends to $f-i k-a$ which in turn, with the introduction of the causative suffix, extends to fisha. Other verbal forms, which, prima facie, look like possible counterexamples, are given under (9):

(9) kumbuka 'remember'

anguka 'fall down'

kurupuka 'dart away'

The three forms, however, are not counterexamples. All of them are essentially stative verbs. For the form kumbuka, for example, the existence of kumbukumbu 'memory' does suggest in a strong way that the true root of kumbuka 'remember' is not kumbuk-, rather kumbu- and the velar consonant / $/$ / was introduced by a stative rule. The other two roots extend as follows:

(10) (a) angu-a 'cause to fall' angu- $k$ - $a$ 'become falling'

angu-sh-a 'cause to become falling'

(b) kurupu-a 'startle/cause to dart away' kurupu-k-a 'be in the darting/startled' kurupu-sh-a 'cause to be in the darting away'

The two examples above give more evidence in support of the claim that -sh-is a causative suffix specific to stative verbs. The semantic contrast between angua and angusha lends support to the claim that the morphological engine of a language does not produce synonyms. A study of angua shows that it is inherently a causative verb expressing the meaning 'make to fall' or 'verb the object'.

Likewise, kurupua has the same semantic content as angua, namely, 'make to dart away'. When these verbs acquire the overt causative, they change their semantic frame from 'verb the object' to 'cause the object to be verbable'. Thus, there is no synonymy between angua and angusha or kurupua and kurupusha. This morphological behaviour is characteristic of many other verbal forms. Verbal forms such as those under (11) exemplify this.

(11) (a) ondoa 'cause to move/remove' ondoka 'be in a state of moving' ondosha 'cause to be in a state of moving'

(b) opoa 'cause to be safe/save' opoka 'be in a state of safety' oposha 'cause to be in a state of safety'

The verbal form dondoa 'pick up' allows the formation of dondosha but not dondoza, as we would expect. We are given to understand that dondoa does not 
participate in the causative suffix introduction rule. Indeed, if it were to apply, the rule would produce dondoza which means 'make someone verb'. Dondoza is semantically different from dondosh $a^{5}$ which means 'cause to become dropping'.

The claim here is that the causative meaning inherent in the root itself is differentiated from the one introduced by the morphological rule. The latter comes in to express 'a state of becoming verbed' whereas the former, the inherent one, expresses the meaning 'cause to verb'.

We might add here that the inherent causative in ondoa expresses an 'actor' meaning. The introduced causative suffix, on the other hand, expresses an 'acted upon' meaning. It is plausible to claim that the difference between the two is that the inherent causative focuses on the subject of the verb, whereas the other focuses on the object. For the sake of clarification, let us study the following sentences in which the two verbs angua and kurupua are in use:

(12) Mosi anaangua maembe 'Mosi is making the mangoes fall' Maembe yanaanguka maembe 'Mangoes are falling down' Mosi amekurupua sungura 'Mosi has startled the rabbit' Sungura amekurupuka 'The rabbit has darted away' Mosi anaangusha maembe 'Mosi is causing the mangoes to be falling' Mosi anakurupusha sungura 'Mosi is causing the rabbit to dart away'

All these examples support the claim that the stative suffix introduction rule feeds the causative rule. ${ }^{6}$ What is also important here is the morphosyntactic patterning of the suffixes. In a dictionary showing possible extensions, it is misleading to indicate that the root pend-is immediately followed by a causative suffix of any kind. It is pendeka 'become/be lovable' which can receive a causative to produce the verbal form pendesha 'cause to be lovable'.

In other contexts, the causative suffix takes various phonetic forms. A verbal form ending in two vowels has the alveolar fricative / $\mathrm{z} /$ for the causative suffix. The sequence of vowels comes about in one of two ways. On the one hand, if the verbal root ends in a vowel, then the vowel suffix becomes the second vowel. On the other hand, a verbal root which has acquired a stative suffix, has the vowel suffix at the end of the verbal form as its second vowel. Thus, on receiving the applicative suffix, pend- becomes pendea and the causative verbal form becomes pendeza which means 'cause to love on account of'. That this is indeed the case, is exemplified by the following set of data.

(13) (a) kaw-a 'delay'

$k a w-i-a$ 'delay someone on account of'

$k a w-i-z-a$ 'cause to delay someone on account of'

(b) chag-a 'work with renewed vigour' chag-i-a 'work with renewed vigour on account of' chag-i-z-a 'cause someone to work with renewed vigour on account of'

The introduction of the reciprocal suffix in (14) below makes the preverbal and postverbal nouns share subjecthood as well as objecthood. The reciprocal suffix 
causes the action of the verb to be bidirectional in which the hitter is simultaneously hit. Let us have a look at the data under (14).

(14) Juma anapenda msichana 'Juma loves a girl' Juma na msichana wanapendana 'Juma and the girl love each other' Juma anapendana na msichana 'Juma and the girl love each other'

Semantically, on the acquisition of the reciprocal suffix, both the subject and the object of the first sentences, namely Juma and msichana, do not only share subjecthood but also objecthood. An intransitive verbal root, however, cannot acquire the reciprocal suffix, because it has a preverbal noun only. Thus, this becomes a constraint when the reciprocal suffix introduces the sharing of subjecthood and objecthood. Likewise, the reciprocal suffix cannot be introduced to a stative verbal form for the same reason. The claim is corroborated by the set of data below in which intransitive verbs are used:

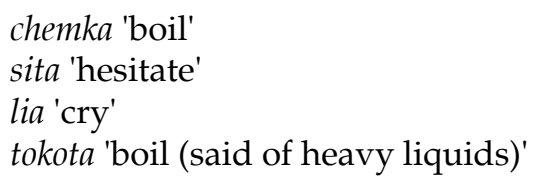

Introducing the reciprocal suffix to any of these verbal forms results in unacceptable verbal forms, as can be seen from the examples under (16) below:

(16) * chemkana 'boil each other' 7

*sitana 'hesitate each other'(?)

*liana 'cry each other'(?)

*tokotana 'boil each other'(?)

Any transitive verb, however, can acquire a reciprocal suffix. Indeed, an intransitive verb that has acquired a causative suffix or an applicative suffix, can acquire the reciprocal suffix. In the following set of data, simple verbal roots are detransitivized by the stative suffix and then retransitivized by the causative suffix:

(17) som- 'read'

som-ek-a 'be readable'

som-esh- $a$ 'cause to be readable' 8

sem- 'say'

sem-ek-a 'be sayable'

sem-esh-a 'cause to be sayable'

imb- 'sing'

imb-ik-a 'be singable'

imb-ish-a 'cause to be singable'

The three verbal forms can convert into reciprocals as under (18).

(18) som-esh-an-a 'make reading accessible to each other' 
sem-esh-an-a 'make saying possible for each other' imb-ishan-a 'make singing possible for each other'

By virtue of the applicative it has acquired, the third verbal form under (3) above, namely pendea, has become a ditransitive instead of a monotransitive verb. In other words, instead of a single postverbal noun, the verbal form has two postverbal nouns. This is readily exemplified by the set of data under (19).

(19) Juma anapenda msichana 'Juma loves a girl'

Juma anampendea nini msichana yule? 'For what reason does Juma like the girl?'

Juma anampendea tabasamu zake 'Juma loves the girl on account of her smiles'

The applicative suffix is introduced on both transitive and intransitive verbal roots. With the introduction of the suffix, intransitive verbal forms become transitive whereas the transitive ones become ditransitive. Intransitive verbs such as the following become transitive following the introduction of the suffix:

(20) $f-a$ 'die' lal-a 'sleep'

$f-i-a$ 'die on account of/against the wish of'

ja-a 'be/become full' ja-li-a 'be/become full for the sake of' $k a-a$ 'sit' $k a-l i-a$ 'sit for/on behalf of/for the sake of/against the wish of'

fa-a 'be suitable' fa-li-a 'be suitable for/suit'

A detailed analysis of this type prevents the lexicographer from making wrong decisions. It is, for instance, misleading to indicate that every verbal root can directly receive a causative suffix in which the meaning remains to be 'cause to verb'. Or, for that matter, the user of the dictionary can be misled into believing that every verbal root can acquire a stative suffix, regardless of whether or not it is transitive. The lexicographical indications found immediately after verb entries suggest that each root can acquire a stative suffix. Yet this does not represent the morphological reality of the language. Intransitive verbs such as gumi-a 'roar', ja-a 'be full', and ish-a 'be finished/exhausted', are inherently stative. Allowing them to acquire the suffix results in verbal forms with double statives that are hard to interpret as can be seen from the following which are neither current nor potential:

$$
\begin{array}{ll}
\text { gumi-a 'roar' } & { }^{*} \text { gum-ik-a } \\
\text { ja-a } a \text { 'be full' } & { }^{j} \text { jal-ik- } a^{9} \\
\text { ish-a } \text { 'be exhausted' } & { }^{*} \text { ish-ik-a } \\
\text { po- } a \text { 'be cool/cold' } & { }^{*} \text { pol-ek- } a^{10}
\end{array}
$$

As far as their semantic patterns go, it can be claimed that verbal forms with single suffixes express compositional meanings. Thus, the meaning of a verbal form carrying a suffix will express the meaning of the root plus that of the suffix. It is however, important to note that, occasionally, a given verbal form may 
carry more than one suffix. Thus, although it is prima facie a single root, a close analysis will reveal that it has another affix which is somewhat invisible as a result of morphophonemic processes it has undergone. In such a situation, the verbal form gives a false reading. The best examples are ondoa and pendea. Without prior knowledge of the verbal forms from which these are derived, chances are that the two causative forms are given the reading 'to verb' instead of 'to be verbed' or 'to be verbing'.

As has been pointed out earlier, each of the verbal forms can convert into a noun. The language has four nominalizing suffixes, namely $-o,-e /-w,-j i$, and $-i$. Each of these nominalizers has a specific meaning; -0 , for example, expresses the result of the action of the verb, the process or the instrument of the verb. Let us study the following examples:

(22) pend-o 'the result of the verbing, love'

pend-an-o 'the result of loving each other'

pend-e-o 'the cause/result of being lovable'

pend-ek-o 'the state of being lovable'

pend-e-sho 'the causal reason for being lovable'

Depending on idiosyncratic features of the root, derived nouns such as those under (22) acquire different noun class prefixes that somewhat modify their meanings. Thus, upendo and mapendo are different. Upendo is 'the feeling of love' whereas mapendo is 'all those acts which reveal the feeling of love'. Likewise, upendano is 'the feeling of loving each other' and mapendano are 'all the acts which reveal the feelings of people who love each other'.

The nominalizers $-i$ and $-j i$ denote the 'doer' of the verb, i.e. they represent the subject of the verb. The former bears an added meaning of a professional verber, a regular doer whereas -ji denotes occasionality, irregularity and lack of expertise and probably lack of seriousness. Thus, mpenzi is someone who loves seriously, unswervingly, whereas mpendaji is an occasional, irregular lover, someone who does not take his/her love seriously. Put differently, although both express the actor or the verber so to speak, they differ in terms of the level of commitment. Mpenzi is much more committed than mpendaji. This phenomenon is not idiosyncratic to the root pend- only, but is also characteristic of the majority of the verbs as the following set of data shows:

$\begin{array}{ll}\text { jenga 'build' } & \text { jenzi } 11 \text { 'builder' } \\ \text { tunga 'compose' } & \text { tunzi 'composer' } \\ \text { panda 'plant (seeds)' } & \text { panzi 'planter of seeds' } \\ \text { unda 'construct' } & \text { unzi 'constructor' } \\ \text { vua 'fish' } & \text { vuvi 'fisherman' } \\ \text { lapa 'eat greedily' } & \text { lafi 'greedy person' }\end{array}$

On the other hand, the nominalizer $-e$ is not used, instead, the verb root idiosyncratically uses the passive marker $-w$ - to form the noun mpendwa 'the beloved one'. Another verbal root which behaves alike is tuma 'send'. This verb 
root derives the noun mtumwa which means 'a slave'. Unlike pend- the verbal root tum- allows the derivation of mtume 'the sent one/prophet'. The verbal root pend- disallows mpende for the meaning 'the beloved one'. Yet, as a nominalizer $-e$ is actively used by a number of verbal roots such as the following:

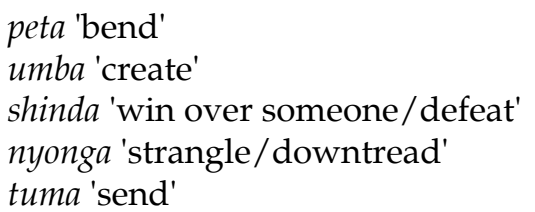

\author{
pete 'ring/something bent' \\ kiumbe 'something created/creature' \\ mshinde 'someone defeated' \\ mnyonge 'someone downtrodden' \\ mtume 'someone sent'
}

Every verbal root in the language idiosyncratically chooses a number of nominalizers which participate in derivational processes involving it. The lexicographer cannot, by mere inspection of the forms, decide on the right nominalizers for the right verbs. Unfortunately the KKS does not point out which nominalizer is used by the root in each of its morphological processes.

What is underscored here is that verbal forms cannot be correctly interpreted without knowing their morphological history. Likewise, when suffix introduction rules are violated, semantic opacity results. When, for example, a stative suffix is introduced to stative verb roots or those which are intransitive, the resulting verbal forms are impossible to interpret semantically. The examples chemkika and gumika given above are good examples of semantic opacity. Let us now investigate verbal forms with more than one suffix.

\subsection{More than one suffix}

When a verbal root acquires a suffix, the resulting verbal form may be used as the input of another suffix introduction rule. Then, once it applies, this rule feeds another suffix introduction rule. In this way, some verbal forms consist of two or more extension suffixes. When the verbal forms under (3) above are allowed to acquire other suffixes, the resulting new forms are those under (25).

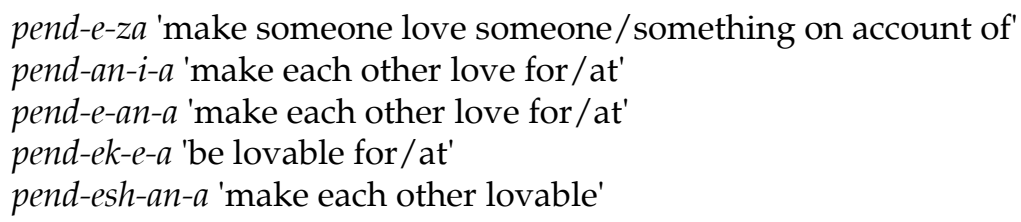

Except for the last, all these verbal forms make use of two suffixes. The first, pendeza, has the applicative followed by the causative suffix. The second, pendania, has the reciprocal followed by the applicative suffix. The applicative suffix follows the reciprocal in the third, pendeana. In the fourth, pendekea, the stative suffix follows the applicative. In the last verbal form, pendeshana, without going into the details of the morphophonemics alluded to earlier, the causative follows the reciprocal suffix. It will be recalled, however, that the introduction of the causative suffix sets in after the stative suffix has been introduced. Thus, to 
begin with, we have pendeka which feeds the causative introduction rule to derive pendesha and then the causative is followed by a reciprocal suffix.

When two suffixes are used simultaneously, a number of morphosyntactic constraints tend to surface. One such constraint is that the applicative suffix cannot follow the stative. If they are used consecutively, the latter must precede the former. This claim is confirmed by the fact that the verbal form in (26)(a) below is unacceptable but (26)(b) is acceptable:

(26) (a) *pend-e-ek-a 'become loving for/on account of'(?)

(b) pend-ek-e-a 'be/become lovable at/on account of'

Likewise, when the causative and the stative are used, the former precedes the latter. Both the applicative and the stative feed the causative introduction rule. The applicative suffix and the reciprocal suffix interchange positions without any consequences, both syntactic and semantic.

In addition to the morphosyntactic constraints, semantic problems surface as well. When two suffixes are simultaneously used, the semantic processing of the verbal form become somewhat enigmatic. Let us study the verbal forms under (25) in the sentences under (27):

(27) (a) Mtoto anapendeza 'The child is attractive'

(b) Watoto wanapendania mali/kwao 'The children like each other on account of wealth/home'

(c) Watoto wanapendeana mali (as under (27)(b))

(d) Shati linapendekea rangi yake 'The shirt is lovable on account of its colour'

(e) Watoto wanapendeshana 'The children are making each other lovable'

In order to process the above sentences accurately, we need to break them up into semantic kernels. In sentence (27)(a) Mtoto anapendeza, for example, the semantic kernels are:

(i) Someone loves the child.

(ii) There is a reason for loving the child.

(iii) It is this reason that causes someone to love the child.

Thus, with these kernels the meaning of the sentence can be couched. Likewise the sentence $(27)(\mathrm{b})$ Watoto wanapendania mali/kwao carries the following kernels:

(i) The children love each other.

(ii) Wealth is the reason for loving each other.

(iii) Their home is where the loving of each other takes place.

What we need to note here is that the use of the applicative suffix introduces ambiguity into the sentences. Thus, pendania can mean 'love each other for' or 'love each other at'. The reading to be decided upon depends on what follows the verbal form. The former reading is arrived at if the verbal form is followed by mali 'wealth' and the latter is arrived at if kwao 'their home' follows. 
Sentence (27)(c) Watoto wanapendeana mali is synonymous with (27)(b). The difference is more of a structural nature, because in (27)(b) the reciprocal precedes the applicative, whereas in (27)(c) the reverse is the case. When we say in Kiswahili Shati linapendekea rangi yake, sentence (27)(d), we mean to underscore three facts. First, someone somewhere loves a shirt. Second, the shirt has the specific feature making it lovable. Third, that specific feature is its colour. By using the two suffixes, namely the stative and the applicative, the speaker is able to effectuate the semantic content the sentence carries.

In (27)(e), the stative does not surface so that the causative -sh-precedes the reciprocal instead. The verbal form pendeshana expresses the stative, the causative and the reciprocal. Analyzed into its kernels, the sentence Watoto wanapendeshana means:

(i) Each child is lovable to the other.

(ii) Each child causes the other to be lovable.

When the two are combined, the verbal form expresses 'induced bidirectional lovability'. This in-depth understanding of the meaning of the verbal form puts the lexicographer in a better position to define it. Such a definition will be based on this bidirectional lovability. The definition of the verbal form in isolation can run somewhat as follows: pendeshana 'be involved in being lovable reciprocally/bidirectionally'.

Although definitions like these may be somewhat abstract, they prepare the ground for well-couched ones based on a thorough semantic analysis. In other words, verbal forms of this type cannot be cited in dictionaries without being adequately characterized.

The fact that verbal forms which combine more than one suffix are semantically intricate, constrains the number of affixes they acquire. On these grounds, each verbal root can only acquire a certain number of suffixes at a time. Theoretically, however, a root can acquire any number of suffixes. Some roots acquire as many as five suffixes as the root pend- does under (28):

pend-ek-e-z-e-an-a

The semantic input of each suffix is as follows:

-ek- 'be/become verbed'

-e- 'for the purpose of/on account/for the sake of'

-z- 'make/cause to become'

$-e-$ 'for the purpose of/on account/for the sake of'

-an- 'each other'

The verbal form analyzed under (28) is a daily-used word in the language. In order to give a characterization, we need to adduce a principle in which each suffix has a specific scope. For example, the stative -ek- covers the root. Thus, pendek-, an extended root, expresses the state of being lovable, i.e. pendek means 'be lovable'. Then the -e-added to pendek- causes pendekea to express the mean- 
ing 'be lovable for the sake of', etc. Let us now derive the meaning of the verbal form bit by bit:

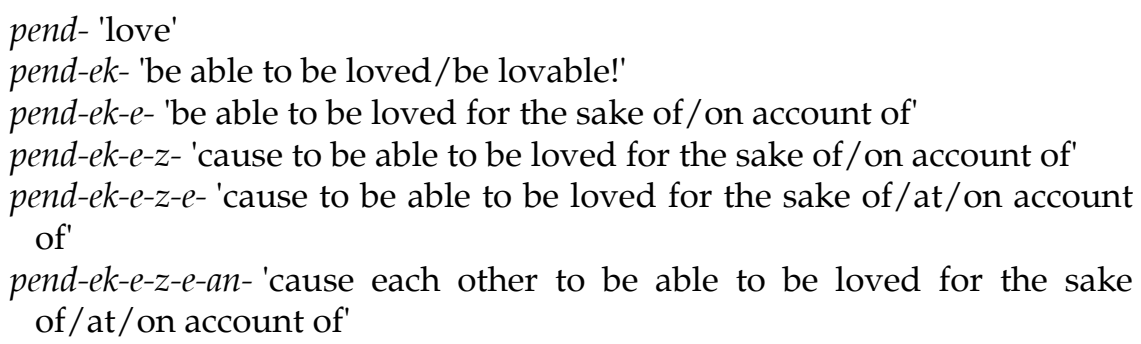

Note, however, that the applicative suffix is repeated. What we are somewhat uncertain about is whether or not, in each instance of its use, it expresses the same meaning. In other words, we are not certain whether or not the applicative suffix in pendekea is different from the one in pendekezea. ${ }^{12}$ We are still uncertain whether a suffix used twice retains its semantic force even when it is used for a second time in the same verbal form. Could it be the case that the next use neutralizes the previous use through a lexicalization process? Although these issues need to be investigated, they are beyond the scope of this article.

If these verbal forms are allowed to nominalize - and theoretically this is possible - the verbal root pend- acquires many nominal derivatives. The following are nouns in use by Kiswahili speakers in their daily communication:

\section{(30) pendekezeano \\ pendekezano \\ pendekezeanio}

From the discussion above, these derivatives may prove to be opaque to a Kiswahili learner. Yet, these and other derivatives need to be indicated and characterized in the dictionary. What is more, even for an ordinary dictionary, the lexicographer is strongly advised to find a way of helping his/her users who come across forms like these for the first time. One suggestion that can be given, is to have both the suffixes and the nominalizers characterized somewhere, if it is impossible to characterize every extension and its derivatives.

\section{Conclusion}

The verbal root pend-is representative of verbs of Bantu origin in Kiswahili. It has both actual and possible word forms it can generate. A dictionary which charts out all these word forms goes a long way to prove that the lexical paucity purported to be characteristic of the language is more imagined than real. A well-compiled Kiswahili dictionary, especially for learners, must show this state of affairs. Indeed, the majority, if not all, Kiswahili speakers, need a dictionary of this type for native speakers per se are, in truth, few. 
In order to achieve this goal, the Kiswahili lexicographer needs to apply the 'enter-them-all' approach proposed by De Schryver and Prinsloo (2001). This approach is not only useful but also user-friendly for a dictionary intended for learners and language developers. It is an approach which, according to these writers, allows the inclusion of 'all the verbs and their derivations likely to be looked up'. When, however, costs must be taken into account, the lexicographer might opt for the 'frequency-based tail slots', or, better still, a combination of the two proposed approaches.

\section{Endnotes}

1. According to Khamis (1972), there are eleven suffixes, two of which are said to be lexical, because they do not change the syntactic patterning of the verbal forms that result.

2. Kiango (2000) does not seem to differentiate between derivation and inflection. According to him, inflection is a class maintaining derivation, whereas derivation par excellence is a classchanging derivation.

3. Kiswahili speakers as a whole are not native speakers of the same level of competence. For many, Kiswahili is a classroom phenomenon, and, for a few who live in urban areas, it is also a street as well as a domestic phenomenon. It is important, however, to add here that the mass-media use of the language has gone a long way in spreading it.

4. This suffix is, according to this article, a variant of the stative suffix. The difference between bomoka and bomoleka is that the former is derived from bomoa whereas the latter is derived from the verbal form bomolea which results from the acquisition of the applicative suffix.

5. Dondosha means 'cause something to drop' rather than 'cause something to be picked up'. With careful interpretation, we arrive at the meaning in which the verbal form calls for an action in the opposite direction.

6. A rule is said to feed another if its application triggers the structural context needed for it to apply.

7. 'Boil each other' makes sense in English, because the verb 'boil' can be used both transitively and intransitively.

8. The way we interpret somesha is 'make someone read' but actually the book is made readable to someone. Kusomesha mtoto shule is 'to make the school accessible to the child'. It is not, we contend, 'to make the child read'.

9. When verbal forms with two vowels extend to acquire either the stative or the applicative suffix, they do so with an introduction of a lateral /1/. This causes them to have two possible readings: jalika is acceptable if it is derived from jalia meaning 'be full for the sake of'.

10. If the sequencing of the extensions in the KKS is anything to go by, poleka is acceptable, because it is derived from polea.

11. After nominalization, the derived noun stem acquires a noun prefix. Thus, after it has been derived, jenzi acquires a noun prefix such as $m$ - for 'the person who verbs' and $u$ - which denotes the verbing skill or process.

12. The suffix, as has already been pointed out, has a homonymic behaviour. It can mean: 'for the benefit of', 'to the detriment of', 'at/on/in' or 'with/by'. That is why it is sometimes referred to as the prepositional suffix. 


\section{References}

Bokamba, E.G. 1981. Aspects of Bantu Syntax. Preliminary edition. Urbana-Champaign: University of Illinois, Department of Linguistics.

De Schryver, G.-M. and D.J. Prinsloo. 2001. Towards a Sound Lemmatisation Strategy for the Bantu Verb through the Use of Frequency-based Tail Slots - with Special Reference to Cilubà, Sepedi and Kiswahili. Mdee, J.S. and H.J.M. Mwansoko (Eds.). 2001: 216-242, 372.

Givón, T. 1971. Some Historical Changes in the Noun-class System of Bantu: Their Possible Causes and Wider Implications. Kim, C.-W. and H. Stahlke (Eds.). 1971. Papers in African Linguistics: 34-54. Edmonton/Champaign: Linguistics Research Inc.

Givón, T. 1971. Historical Syntax and Synchronic Morphology: An Archaeologist's Field Trip. Papers from the Seventh Regional Meeting, Chicago Linguistic Society, April 16-18, 1971: 394-415. Chicago: Chicago Linguistic Society.

Gleason, H.A. 1967. The Relation of Lexicon and Grammar. Householder, F.W. and S. Saporta (Eds.). 1967: 85-102.

Householder, F.W. and S. Saporta (Eds.). 1967. Problems in Lexicography. Bloomington: Indiana University/The Hague: Mouton and Co.

Keach, C.B. 1985. The Syntax and Interpretation of the Relative Clause Construction in Kiswahili. New York/London: Garland Publishing.

Kenstowicz, M. and C. Kisseberth. 1979. Generative Phonology: Description and Theory. New York/London/Toronto: Academic Press.

Khamis, A.M. 1972. A Consideration of Grammatical Roles in Swahili. Unpublished M.Phil. Thesis. York: University of York.

Kiango, J.G. 2000. Bantu Lexicography: A Critical Survey of the Principles and Process of Constructing Dictionary Entries. Tokyo: Institute for the Study of Language and Cultures of Asia and Africa (ILCAA).

Mdee, J.S. and H.J.M. Mwansoko (Eds.). 2001. Makala ya kongamano la kimataifa Kiswahili 2000. Proceedings. Dar Es Salaam: TUKI, Chuo Kikuu cha Dar Es Salaam.

Prinsloo, D.J. and G.-M. de Schryver. 2001. Taking Dictionaries for Bantu Languages into the New Millennium - with Special Reference to Kiswahili, Sepedi and Isizulu. Mdee, J.S. and H.J.M. Mwansoko (Eds.). 2001: 188-215.

Radford, A. 1997. Syntactic Theory and the Structure of English: A Minimalist Approach. Cambridge: Cambridge University Press.

Kamusi ya Kiswahili Sanifu. 2004. Dar Es Salaam: Oxford University Press.

Vitale, A.J. 1981. Swahili Syntax. Dordrecht, Holland/Annaminson, U.S.A.: Foris Publications.

Weinreich, U. 1967. Lexicographic Definition in Descriptive Semantics. Householder, F.W. and S. Saporta (Eds.). 1967: 25-44.

Zgusta, L. 1971. Manual of Lexicography. The Hague/Paris: Mouton. 